\title{
IDENTIFIKASI DIRI DAN PEMBENTUKAN IDENTITAS DIRI KARYAWAN DALAM PROSES RESTRUKTURISASI ORGANISASI
}

\author{
Mustadin $^{1}$, Fathul Himam ${ }^{2}$ \\ ${ }^{1}$ Fakultas Ilmu Sosial dan Humaniora, Program Studi Psikologi, Universitas Islam \\ Negri Sunan Kalijaga, Jl. Marsda Adisucipto, Yogyakarta, Indonesia. \\ ${ }^{2}$ Fakultas Psikologi, Universitas Gadjah Mada, Jl. Sosio Humaniora, Bulaksumur, \\ Yogyakarta, Indonesia, 55281. \\ ${ }^{1}$ mustadin82@gmail.com, ${ }^{2}$ fhimam@gmail.com
}

\begin{abstract}
Organization restructuring is a common phenomenon which is applied in order to improve organizational performance. Unfortunately, many restructuring processes often neglect their impacts on employees. This phenomenological research was directed to cover some issues related to the impact of organization restructuring on employees' behavior, particularly on the way employees' self identification were developed and how these experiences shape employes' self identity. In-depth interviews were employed to collect the data that involved 10 employees from UIN Sunan Kalijaga Yogyakarta and UIN Sultan Alauddin Makassar as respondents. Phenomenology approach is used in this research, and the process of analyzing and interpreting data used Stevick-Colaizzi-Keen technique. Member checks and external audits were used to verify the trustworthiness of the data. This research concluded four major themes related to how employees' self identity was developed and how employees put its meaning. The themes were (1) be a Learner; (2) surrender to his or her destiny; (3) being active and flexible; (4) be independent. These identities had unique implication toward employees'work behaviors in organization.
\end{abstract}

Keywords: employee's self identity development, organizational change, organizational restructuring.

\begin{abstract}
Abstrak
Restrukturisasi organisasi adalah fenomena umum yang diterapkan untuk mengembangkan kinerja organisasi. Akan tetapi proses restrukturisasi seringkali memunculkan dampak pada individu atau karyawan dalam organisasi. Penelitian dengan menggunakan pendekatan fenomenologi ini dilakukan untuk mengungkap isu yang melingkupi proses resktrurisasi organisasi yang berdampak pada perilaku karyawan. Penelitian ini melibatkan 10 responden (UIN Sunan Kalijaga Yogyakarta dan UIN Sultan Aladuddin Makassar) untuk mengungkap bagaimana identifikasi diri karyawan dikembangkan dan membentuk identitas individu karyawan dalam konteks perubahan organisasi. Indepth interview digunakan untuk mengungkap data dalam penelitian fenomenologi ini, kemudian dilakukan anaslisis data dengan tekenik StevickColaizzi-Keen. Guna melakukan ferivikasi dan uji keterpercayaan hasil penelitian,
\end{abstract}


dilakukan teknik external audit dan member check. Hasil penelitian ini menghasilkan 4 (empat) tema besar yang menunjukkan bagaimana identitas diri karyawan dikembangkan dalam proses restrukturisasi dana maknanya bagi kehidupan kerja karyawan. Tema-tema tersebut antara lain: (1) Pembelajar, (2) Pasrah, (3) Fleksibelaktif 4) Sempalan. Tema-tema tersebut memiliki implikasi yang berbeda-beda dalam kehidupan kerja karyawan.

Kata Kunci: perkembangan identitas diri karyawan, perubahan organisasi, restrukturisasi organisasi

\section{Pendahuluan}

Pasca kajian Fredrick Taylor yang ditulis Mason (2004) mengenai perubahan organisasi, penelitian-penelitian tentang perubahan organsiasi pun semakin berkembang. Pada tahun 1951, Kurt Lewin menggagas sebuah ide dalam menggambarkan proses perubahan dalam organisasi yang terkenal dengan istilah unfreezing, movement, dan refreezing. Perubahan dalam berbagai aspek lingkungan organisasi, seperti perubahan sosial, perubahan politik, perubahan tata ekonomi dunia, perubahan teknologi mengambil peran masing-masing dalam mempengaruhi perubahan organisasi (Cummings \& Worley, 2005).

Perubahan yang muncul dan yang terjadi dalam organisasi ialah sebuah fenomena yang tidak bisa dihindari, hal ini disebabkan oleh beberapa faktor utama yang mempengaruhinya, diantaranya; globalisasi, teknologi informasi, dan inovasi manajerial (Cummings \& Worley, 2005). Pengaruh globalisasi memberikan dampak perubahan pada lingkungan persaingan dan pasar, persaingan ketat ini memaksa organisasi dan setiap individu untuk menyesuaikan diri agar mampu bertahan, sedangkan pada perkembangan bidang teknologi informasi dalam proses organisasi membawa dampak pada jumlah penggunaan tenaga kerja serta biaya yang digunakan dalam organisasi (Kreitner \& Kinicki, 2003; Cummings \& Worley, 2005).

Proses perubahan yang terjadi dalam organisasi tersebut, menyebabkan individu mengembangkan jenis sikap personal (personal attitude), sebagai bentuk ekspresi perasaan dan emosi guna mencari bentuk bagaimana mereka harus menyesuaikan diri terhadap situasi yang tidak familiar bagi karyawan tersebut. Sikap personal ini bisa berwujud sikap yang negatif akan tetapi juga bisa memunculkan respon dan sikap yang positif (Himam, 2002;2005). Untuk bertahan pada pekerjaannya misalnya, para karyawan yang bersikap negatif akan memunculkan sikap berpura-pura optimis dalam menghadapi tantangan pekerjaannya. Mereka akan memakai "topeng" dalam kehidupan kerjanya. Hal ini hanya untuk menutupi ketidakmampuan mereka untuk memecahkan masalah kerjanya (Himam, 2002). Pemunculan diri (self) dalam bentuk yang tidak sebenarnya inilah yang akan membawa dampak pada upaya pencarian diri yang lain (Lhutans, 2002). Eksistensi yang tampak akan berbeda dari yang sebenarnya. Inilah yang disebut konflik super ego dan ego yang akan memunculkan kondisi disequilibrium dalam mental individu.

Konsep topeng adalah topeng yang dipakai sang pribadi sebagai respon terhadap tuntutan-tuntutan kebiasaan dan tradisi masyarakat. Hal ini merupakan peranan yang diberikan oleh masayarakat atau lingkungan kerja kepada seseorang. Tujuan topeng ini adalah untuk menciptakan kesan tertentu pada orang-orang lain untuk menyembunyikan 
hakikat pribadi yang sebenarnya. Apabila ego (kesadaran) mengedentifikasikan diri dengan persona, sebagaimana seringkali terjadi, maka individu akan menjadi lebih sadar akan bagian yang dimainkannya daripada terhadap perasaannya yang sebenarnya (Lhutans, 2002; Himam, 2002).

Identifikasi diri yang tepat pada berbagai konteks akan mempengaruhi peningkatan kemampuan diri seseorang, mengidentifikasi diri pada kelompok yang tidak berdaya atau minoritas mampu mempengaruhi keterlibatan pada proses yang terjadi dilingkungan sekitar individu tersebut (Wood., Pool., Leck., \& Daniel, 1996). Keterlibatan pada proses di lingkungan kerja karyawan dapat menentukan masa depan karir karyawan itu sendiri. Karyawan yang memiliki sikap yang positif akan memiliki harapan bahkan kebanggaan ketika mampu bertahan dalam kondisi kerja yang berubah (Wood., et al. 1996). Konsistensi dalam perwujudan sikap dalam organisasi baik dalam konsisi normal atau dalam situasi perubahanorganisasi akan membawa pada keselarasan antara aktivitas mental dan apa yang ditampakkan dalam kehidupan kerja karyawan (Himam, 2002)

Mengidentifikasi diri pada kelompok atau karakteristik yang positif atau mengasosiasikan diri ke dalam acuan yang lebih baik dapat membawa pada kemampuan diri yang lebih baik dibandingkan dengan mengidentifikasikan diri kedalam kelompok atau karakteristik yang negatif (Wood., dkk. 1996; Maiping, 1996; Chen, \& Shaw, 2004; Fuller., Marler., Hester., Frey., \& Relyea, 2006). Kegagalan pada pengidentifikasian diri pada karakteristik atau kelompok yang muncul dalam proses perubahan organisasi juga dapat membawa individu atau karyawan memunculkan starategi atau "taktik menyembunyikan diri" (Himam, 2002). Padahal "taktik menyembunyikan diri" dalam situasi perubahan organisasi mendorong karyawan memunculkan bentuk mekanisme proyeksi seperti rasionalisasi, atau sekalian menghindar dari perubahan tersebut dan yang lebih buruk lagi adalah sampai pada tahap resisten terhadap perubahan organisasi yang berjalan.

Tujuan penelitian ini adalah untuk memahami bagaimana dinamika proses identifikasi diri karyawan dalam konteks restrukturisasi organisasi. Hal ini akan membawa pada pemahaman yang lebih mendalam akan proses diri karyawan dalam melihat dan mengidentifikasi diri dalam proses perubahan organisasi, serta dampaknya pada kemampuan untuk mengahadapi tekanan kerja atau perubahan tuntutan-tuntutan kerja yang mereka hadapi dalam proses restrukturisasi organisasi sehingga mereka mampu bertahan dan berkembang dalam organisasi.

1. Pertanyaan utama penelitian: Bagaimana dinamika dan proses identifikasi diri karyawan dalam konteks restrukturisasi organisasi?

2. Sub pertanyaan:

a. Apa makna identifikasi diri karyawan dalam proses restrukturisasi organisasi?

b. Bagaimana pola atau bentuk identifikasi diri karyawan dalam proses restrukturisasi organisasi?

c. Kearah mana identifikasi diri karyawan digerakkan dalam proses restrukturisasi? 


\section{Metode Penelitian}

Penelitian ini menggunakan model pendekatan fenomenologi dalam memahami realitas empiris yang menjadi fokus kajian di lapangan. Hal ini dipilih guna memudahan peneliti memahami pengalaman identifikasi diri serta arah perkembangan identitas karyawan dalam proses restrukturisasi organisasi. Jumlah responden yang diwawancarai yang diperoleh dengan menggunakan teknik snow bowling. Kemudian diperoleh 6 orang subjek yang bekerja pada perusahaan BSW Corporation yang selanjutnya dijadikan sumber analisis data.

Analisis data dilakukan sesuai dengan pendekatan fenomenologi yang djelaskan oleh Moustakas (1994). Hal ini dikarenakan metode analisis dan interpretasi data modifikasi metode Stevick-Colaizzi-Keen dari Moustakas tersebut ialah metede yang paling sering digunakan oleh peneliti fenomenologi dengan tahapan yang sistematis dan lengkap. Prosedur analisis dan interpretasi data meliputi :

1. Deskripsi tentang pengalaman peneliti terhadap phenomenon.

2. Indentifikasi pernyataan (dalam interview) mengenai bagaimana individu-individu mengalami topik (phenomenon) tersebut, membuat daftar dari pernyataanpernyataan tersebut (horizonalization) dan perlakukan tiap pernyataan dengan seimbang (mempunyai nilai yang sama), dan mengembangkan daftar dari pernyataan yang tidak berulang (nonrepetitive) atau tidak tumpang tindih (nonoverlapping).

3. Pengelompokkan pernyataan-pertanyaan kedalam unit-unit makna (meaning units). Hal ini dilakukan dengan membuat daftar dari unit-unit ini, dan menuliskan deskripsi dari tekstur (deskripsi tekstural) dari pengalaman, yaitu apa yang terjadi, disertai contoh-contoh verbatim.

4. Refleksi berdasarkan deskripsi sendiri dan menggunakan imaginative variation atau deskripsi struktural, mencari semua makna yang memungkinkan dan perspektif yang divergen, memperkaya kerangka pemahaman dari phenomenon, dan membuat deskripsi dari bagaimana phenomenon dialami.

5. Penyusunan deskripsi keseluruhan dari makna dan esensi dari pengalaman.

6. Penyusunan composite textural-structural description dari makna-makna dan esensi pengalaman, mengintegrasikan semua deskripsi tekstural-struktural individual menjadi deskripsi yang universal dari pengalaman, yang mewakili kelompok (responden) secara keseluruhan (Moustakas, 1994).

Guna memastikan validitas dari penelitian ini, peneliti menggunakan intersubjective validity atau melakukan klarifikasi hasil rumusan situasi diri dan pengalaman karyawan yang ditulis peneliti kepada semua responden yang dilibatkan. Selanjutnya dilakukan external audit atau menunjukkan hasil penelitian kepada ahli dalam bidang yang diteliti agar sejalan dengan konsep teoritis yang dipahami oleh ahli tersebut.

\section{Hasil dan Pembahasan}

Pada proses restrukturisasi karyawan terjadi pemindahan atau penataan ulang karyawan yang bekerja dalam organisasi (rightsizing) serta perampingan organisasi. Hal ini menimbulkan karakter baru dalam lingkungan organisasi antara lain: lingkungan kerja baru; pekerjaan baru dan tanggung jawab baru; jabatan baru; ritme kerja baru. 
Para karyawan yang dipindahkan memandang bahwa lingkungan pekerjaan baru yang mereka miliki bisa saja menjadi awal dari perubahan, sehingga mereka tetap waspada akan kemungkinan dikeluarkan walaupun sudah dipindahkan. Sebenarnya ada juga karyawan yang menganggap bahwa perubahan yang muncul tidak jauh berbeda dengan kondisi perusahaan yang lama, yang berbeda cuma interaksi dengan lingkungan perusahaan yang baru terbentuk, diantaranya relasi kerja dan pimpinan.

Perubahan relasi kerja atau cakupan wilayah kerja membuat karyawan melihat perlunya untuk beradaptasi terhadap hal-hal tersebut, besarnya perubahan jaringan kerja diangap sebagai sebuah pekerjaan baru yang perlu untuk diadaptasi. Fakta lain menunjukkan bahwa ada karyawan yang melihat pekerjaan baru adalah tanggung jawab baru yang harus disikapi dan diselesaikan lebih cepat dari sebelumnya.

Saat terjadinya perombakan struktur organisasi, secara simultan, perusahaan membentuk beberapa unit baru dalam perusahan. Karyawan juga melihat bahwa jabatan yang baru sebagai sebuah hal yang berbeda dengan pola, lingkungan dan cakupan wilayah kerja sebelumnya. Karyawan dalam hal ini membutuhkan peningkatan kemampuan baru dan upaya penyesuaian yang terarah dan terencana dengan baik.

Perubahan yang sifatnya struktural seharusnya membawa dampak pada perubahan berbagai macam sistem dalam organisasi, begitupun pada pola kerja yang bergerak pada pencapaian efektivitas dan efisiensi kerja dalam organisasi, bahkan pencapaian totalitas para karyawan dalam pencapaian tujuan perubahan organisasi. Tuntutan pencapaian organisasi atau perusahaan menimbulkan dampak terhadap ritme kerja karyawan. Hal ini juga menjadi bagian dari tuntutan yang harus diselaraskan oleh karaywan.

Pencapaian tujuan perubahan dengan adanya totalitas kerja juga digambarkan dalam pernyataan responden ini;

"...Kurang lebih sama saja..kalo disini misalnya kadang kami pulang pada jam 21.00, padahal kantor pulangnya jam 17.00, itu karena adanya tuntutan bahwa diawal bulan harus ada closing laporan..maksudnya ritme kerja ya..saya sesuaikanlah dengan yang ada disini..tuntutan pekerjaan.."

Pengalaman karyawan yang muncul dalam perubahan atau dalam proses restrukturisasi bermacam-macam, hal ini disebabkan kondisi perubahan yang mereka miliki berbeda-beda, ada yang mendapatkan informasi yang akurat akan perubahan, dan ada pula yang mendapatkan janji jabatan yang lebih baik dari sebelumnya. Beberapa pengalaman reaksi psikologis karyawan dalam proses restrukturisasi organisasi antara lain: merasa terancam; malas-malasan; tidak bersemangat kerja; cemas; pusing; khawatir; merasa tersingkir; merasa potensi tidak tersalurkan; terbawa kondisi pekerjaan lama.

Kesadaran akan kemampuan diri baik yang menunjang organisasi atau tidak sangat menentukan respon setiap karyawan terhadap fenomena restrukturisasi organisasi, misalnya karyawan yang merasa kurang produktif lagi baik dari segi kemampuan maupun dari segi usia. Karyawan yang merasa tidak mampu mengakomodir tuntutan perubahan perusahaan merasa menjadi bagian dari yang akan mendapat dampak buruk dari tuntutan perubahan perusahaan.

Respon malas-malasan ini bisa muncul dikarenakan oleh ketakutan akan dinilai "cari muka" oleh manajemen, sehingga dikarenakan hal tersebut, karyawan menjadi "malas" untuk bekerja. Ketakutan akan penilaian terhadap kinerja yang dianggap "cari 
muka" inilah yang juga menyebabkan karyawan "malas" atau tidak bersemangat dalam melaksanakan tugas yang dimilikinya

’..kita jadi dak terlalu bersemangat kerja kemudian kita malah malas-malasan karena kalu rajin juga nanti dikirain cari muka untuk tidak dikeluarkan..jadi ya..banyak pekerjaan yang terbengkalai dan dicuekin saja.."

Restrukturisasi memunculkan ketidakpastian bagi sebagian karyawan, sehingga menimbulkan rasa "cemas" bagi karyawan. Bahkan sampai "saling mencurigai" satu sama lain.

"..melihat bahwa akan ada banyak perubahan yang akan terjadi diperusahaan ini, dan kami harus siap-siap akan konsekuensi yang akan ditimbulkan restrukturisasi ini. Cuma..kadang kami bingung mau berubah jadi apa perusahaan ini? E...sehingga kami merasa cemas. Jangan-jangan saya yang kena.jangan-jangan siapa yang kena? Ya..begitulah..saling mencurigai siapa yang akan menjadi korban dan yang akan selamat dalam restrukturisasi ini.."

Munculnya kecemasan sebenarnya sebagai gambaran atau reaksi terhadap ketidakpastian akan kondisi perusahaan, sehingga untuk mengantisipasi rasa "cemas" yang dialami para karyawan dalam proses restrukturisasi organisasi, karyawan memunculkan pandangan yang positif terhadap ketidak pastian tersebut.

Kompleksitas dampak yang ditimbulkan dalam proses restrukturisasi memunculkan berbagai macam efek bagi kayawan. Perubahan kerja, jabatan/profesi, serta pergaulan dengan orang-orang baru membuat karyawan menjadi "pusing" dalam menghadapinya. Situasi yang kompleks yang diliputi oleh berbagai implikasi negatif bagi karyawan termanifestasi dalam bentuk "kepasrahan". Kepasrahan yang muncul pada diri karyawan bisa digambarkan sebagai wujud ketidak berdayaan dalam menghadapi ancaman pemutusan hubungan kerja (PHK).

Penghilangan bagian dalam organisasi menimbulkan dampak pemindahan sebagian karyawan kedalam bidang lain, pemindahan tersebut secara otomatis memunculkan pembauran dalam bidang atau bagian tertentu. Disadari atau tidak, hal ini memunculkan fenomena tersendiri bagi karyawan yang sudah ada sebelumnya dalam bidang tersebut, seperti merasa "tersingkir" dengan para pekerja yang baru bergabung dalam lingkungan mereka. Merasa "tersingkir" dalam perusahaan kemudian menimbulkan masalah baru. Perasaan tersebut mampu menimbulkan efek karyawan tidak patuh terhadap perusahaan.

Memperbandingkan jabatan atau pekerjaan lama dengan yang baru adalah hal yang wajar, akan tetapi ketika muncul rasa "lebih baik" kondisi pekerjaan sebelumnya dapat memunculkan masalah baru. Hal yang lain yang memunculkan rasa "potensi tidak tersalurkan" adalah persolan "pelibatan" dalam proses perubahan. Karyawan merasa hanya mengikuti perubahan tanpa "pelibatan" yang cukup dalam prosesnya.

Perbandingan antara posisi atau pekerjaan yang baru dan pekerjaan sebelumnya yang dijelaskan sebelumnya, memunculkan berbagai macam fenomena pada diri karyawan. Tantangan pada pekerjaan baru menjadi faktor yang mendorong karyawan untuk memulai menekuni pekerjaan atau jabatannya yang baru. 
"tapi kalo tidak ada tantangan ya..saya kasi tau aja keluarga bahwa saya akan keluar..walaupun saya akui kami ini belum punya apa-apa..e..yang penting itu tadi.kalo sudah tidak ada lagi tantangan, kenapa mesti harus didalam? Makanya..saya masih tebawa-bawa kondisi pekerjaan yang lama..mudahmudahan minggu ini saya sudah bisa memualai, mungkin cari momentumnya aja ya..saya nggak ini ya..kalo seandainya sudah dapat mmomentumnya banyak hal yang bisa saya lakukan.. biasanya satu malam sudah bisa mulai.”.

Menghadapai ketidak pastian perubahan lingkungan dalam organisasi serta mengadaptasi perubahan yang terjadi membuat karyawan mengembangkan strategi didalam mengadaptasi perubahan tersebut, strategi coping yang dikembangkan oleh karyawan dalam proses restrukturisasi organisasi tersebut antara lain; bersosialisasi; banyak belajar; banyak bertanya. Memasuki lingkungan baru dan kondisi pekerjaan baru dalam organisasi membuat karyawan harus beradaptasi dengan berbagai macam cara. Salah satunya adalah dengan "bersosialisasi" dengan para karyawan yang sudah lama didalam organisasi tersebut serta relasi kerja baru dalam organisasi. Melakukan "sosialisasi" pada saat baru masuk kedalam lingkungan kerja yang baru, bertujuan untuk membangun relasi dengan para karyawan yang sudah lama didalam perusahaan

"...kemudian mencoba bergaul dengan lingkungan yang baru ya.. bersosialisasilah dengan lingkungan baru maksudnya dengan orang-orang baru di bidang accounting cash flow., dan mudah-mudahan pengurangan atau pemindahan karyawan tidak ada lagi ya.. jadi kita bisa bekerja dengan tenang..."

Bersosialisasi dalam situasi yang tidak menentu menjadi upaya sederhana dalam membangun jejaring. Akan tetapi disisi yang lain tuntutan pekerjaan baru membutuhkan kemampuan beradaptasi yang baik, terutama pada teknis pekerjaan yang dianggap baru bagi karyawan. Oleh sebab itu karyawan terus mengembangkan keinginan untuk "belajar" hal-hal yang belum diketahui dari proses belajar dan pengalaman kerja sebelumnya.

Bertahan di dalam organisasi yang terus melakukan perubahan juga memaksa karyawan yang mau bertahan dan berkembang dalam organisasi, bahkan karyawan dituntut untuk terus mempelajari berbagai fenomena baru dalam organisasi. Akhirnya belajar dan beradaptasi adalah pilihan satu-satunya sebagian karyawan yang masih ingin terus berkarir dan mengembangkan diri dalam perusahaan.

“...Kalo bagi saya sendiri e.. mungkin saya harus lebih banyak belajar dengan orang yang lebih senior dipekerjaan, banyak bertanyalah.. kemudian mencoba bergaul dengan lingkungan yang baru ya.."

Selain kemauan belajar dan beradaptasi tersebut, karyawan seringkali membutuhkan "mentoring" dari para karyawan yang telah terlebih dahulu di lingkungan tersebut. Oleh sebab itu dalam memasuki lingkungan serta kondisi pekerjaan yang baru, karyawan membutuhkan arahan dan petunjuk oleh orang yang terlebih dahulu berada dalam organisasi.

Dinamika perubahan yang memunculkan berbagai macam karakteristik baru dalam organisasi baik langsung maupun secara tidak langsung membentuk perilaku 
baru dan identitas baru pada karyawan, beberapa arah identitas yang dimunculkan dalam proses perubahan organisasi adalah: pembelajar; fleksibel aktif; sempalan; dan pasrah.

Lingkungan kerja baru, bergaul dengan orang-orang baru serta mendapatkan pekerjaan yang tidak sama dengan pekerjaan sebelumnya memaksa karyawan yang ingin beradaptasi untuk menjadi individu yang "pembelajar" agar mampu menjawab tantangan perubahan dalam organisasi. Pembelajar selalu melihat situasi yang ada sebagai bagian dari proses karir yang harus terus dipelajari dan diadaptasi. Karyawan yang "pembelajar" melihat perubahan sebagai fakta baru yang harus dipelajari dan selalu mencari cara mengadaptasi diri, bertanya dengan rekan kerja maupun atasan jika ada hal yang baru dihadapi selalu menjadi cara efektif bagi karyawan "pembelajar" ini.

Menghadapi perubahan lingkungan dan tuntutan kerja yang terus mengalami perubahan, dibutuhkan kondisi diri yang mampu masuk kedalam berbagai tuntutan yang baru dalam organisasi tersebut, dan salah satu karakter yang dikembangkan oleh karyawan dalam proses perubahan organisasi adalah "fleksibel-aktif" terhadap lingkungan dan tuntutan organisasi. Memasuki lingkungan dan pekerjaan baru menuntut karyawan menyesuaikan diri. Perubahan yang terus berlangsung dan lingkungan yang terus berubah membuat karyawan harus menjadi "fleksibel" dan "aktif" dalam melihat tantangan baru dalam proses perubahan tersebut. Fleksibel-aktif dapat diartikan sebagai bentuk dari daya lentur karyawan dalam situasi baru atau situasi yang tidak familiar, selain daya lentur ini, karyawan juga memiliki sikap pro aktif setiap momentum yang muncul dalam organsiasi.

"Kalo saya pribadi saya menggunakan prinsip air,jika ditempatkan diwadah yang bulat, saya akan bulat kalo saya ditempatkan diwadah yang cekung saya akan cekung juga ya.. fleksibel lah..."

Ketidak puasan terhadap perubahan dan merasa tidak diuntungkan oleh proses perubahan yang ada mampu mengarahkan karyawan untuk menjadi orang yang "sempalan" artinya karyawan tidak patuh dan suka melanggar aturan organisasi, sarta suka keluar kantor pada jam kerja perusahaan, bahkan mencari-cari kesempatan untuk pindah dan keluar dari organisasi. Karyawan yang menjadi "sempalan" ini malah terkadang menginginkan dirinya yang masuk dalam daftar para karyawan yang akan diberhentikan.

”..tapi belakangan kan karena saya bosan karena..saya capek dalam kondisi seperti itu..saya berharap..saya mulai saya menyempal..keluar-keluar..tidak menaati aturan. Pernah saya jadi konsultan pada bulan ramadhan inilah..saya jadi konsultan di PLN, saya pergi saja tidak beritahu apa-apa keperusahaan, ya..itupun menurut saya pribadi saya berharap saya masuk dalam daftar..dan terkena proses restrukturisasi”.

Perubahan pekerjaan dan perpindahan jabatan dalam proses perubahan organisasi membuat karyawan merasa terancam, dan setelah mendapatkan kepastian kerja pasca pemindahan, karyawan yang merasa "sama saja dengan pekerjaan yang sebelumnya" mengembangkan konsep "pasrah" dalam dirinya, artinya; mau kemana arah perubahan dan seperti apa nasib yang akan dialami ketika terjadi perubahan lagi, karyawan tersebut hanya mampu menerimanya saja. 
Karyawan juga mengembangkan prinsip "pasrah" dikarenakan ketidak mampuan untuk membaca arah perubahan, yang mana perubahan yang terjadi ini bisa saja berimplikasi pada kehidupan kerja mereka, bahkan yang terburuk adalah mereka termasuk yang akan di PHK pada pengurangan karyawan selanjutnya

"....Wah kalo dampaknya ya..agak susah ya menjelaskannya, Cuma saya begini.. mungkin yang muncul adalah kondisi yang tidak terpikirkan atau e..sulit untuk ditebak, jadi mau tidak mau untuk tinggal diperusahaan ini harus banyakbanyak pasrah.."

Identitas diri yang dikembangkan serta strategi adaptasi yang dimiliki oleh para karyawan menimbulkan implikasi baik langsung maupun tidak langsung terhadap kehidupan kerja mereka pada proses restrukturisasi organisasi yang berlangsung; beberapa implikasi dari strategi adaptasi serta pengembangan karakter dan identitas diri karyawan dalam proses rerstrukturisasi organisasi antara lain: bekerja dengan maksimal; selalu "Siap" akan konsekuensi yang akan timbul; penyesuaian terhadap organisasi; kehilangan arah; tidak bersemangat bekerja.

Karyawan mampu mengembangkan diri, meningkatkan maksimalisasi kerja, serta meningkatkan semangat kerja yang dimilikinya, yaitu ketika karyawan memiliki kepastian arah perubahan yang ada dalam organisasi. Kepastian arah perubahan serta bentuk perubahan baik yang mereka alami langsung seperti posisi kerja atau model organisai, memungkinkan karyawan untuk bekerja dengan maksimal.

Karyawan yang bertahan dan terhindar dari pengurangan karyawan (PHK) juga memiliki rasa "bangga" sehingga hal ini membuat karyawan lebih terdorong untuk "giat bekerja". Banyak harapan terhadap implikasi yang karyawan harapkan dari bekerja dengan maksimal, salah satunya ialah menjadi bagian dari strategi menghadapi proses perubahan yang terus terjadi.

"Bekerja dengan maksimal" bisa saja tidak berangkat dari kesadaran diri sendiri, akan tetapi muncul dan dipengaruhi oleh kondisi organisasi. Lingkungan perusahaan atau organisasi menjadi penopang utama pencapaian efektivitas dan efisiensi dalam organisasi. Lingkungan organisasi ini berimplikasi langsung pada kehidupan kerja para karyawan.

Perubahan organisasi yang menuntut perubahan diri karyawan agar mampu untuk menyesuaikan diri, memang diakui merubah diri karyawan, akan tetapi perubahan pada tataran prinsip mendasar pada diri karyawan belum tentu terjadi pada semua karyawan. Oleh sebab itu berbagai faktor terlibat dalam membentuk respon karyawan atas perubahan organisasi. Faktor ini bisa muncul atas pengkondisian organisasi misalnya proses pendidikan atau pelatihan, bisa juga dari internal karyawan misalnya upaya proaktif dalam mendorong perubahan itu sendiri.

"...Saya bekerja sesuai dengan aturan yang ada ditempat itu, adapun kalo misalnya bertentangan dengan prinsip-prinsip kerja saya, sebisa mungkin itu bekerja dengan maksimal tanpa merubah saya.karena yang kemarin tanggung jawabnya sama saja.."

Kesiapan akan konsekuensi yang bisa saja timbul dalam proses perubahan organisasi menjadi hal yang harus dimiliki oleh karyawan untuk tetap bertahan dan berkembang. Perubahan dalam konteks apapun selalu harus disikapi sebagai sesuatu 
yang "wajar". Sikap seperti ini mampu membantu karyawan untuk menghadapi konsekuensi apapun yang muncul dalam perubahan organisasi.

Keinginan untuk keluar organisasi yang mengalami proses perubahan juga dialami oleh sebagian karyawan, ketidak pastian serta merasa lebih baik pada situasi dan kondisi pekerjaan yang sebelumnya membuat karyawan merasa mengalami "ketidak pastian" serta merasa apa yang dijalaninya sekarang adalah "kehilangan arah". Ketidak pastian dan kehilangan arah dalam situasi yang terus berkembang memunculkan perasaan ingin kembali ke situasi sebelum perubahan organisasi dimulai, begitupun dengan nilai-nilai kerja yang berlaku dalam organisasi sebelum perubahan.

"..ditawarin jabatan ini..tapi saya dak terima, saya dak mau dalam organisasi yang kehilangan arah gitu.. mungkin seperti itu. kalo saya menilai ya..secara subjektif saya ya.. berkarakter disana maksudnya sebelumnya...,kalo diberi kesempatan ya..saya mungkin balik..artinya kembali kepada nilai-nilai yang dulu.. kalo diberi kesempatan ya..kenapa dak balik ke suasana yang dulu.."

Merasa potensi yang tidak tersalurkan dalam lingkungan kerja yang baru serta ketidak pastian perubahan organisasi, hal ini membawa dampak pada karyawan dalam organisasi yang sedang melakukan restrukturisasi. Karyawan yang merasa potensinya tidak tersalurkan mampu menimbulkan rasa frustasi terhadap kondisi yang dialaminya. Pelibatan pada jabatan baru ini akan mampu membentuk karakter kerja yang dimiliki karyawan kedepan.

"Tantangan" dalam dunia pekerjaan sangat dibutuhkan oleh karyawan yang baru dipindahkan, potensi dan kemampuan yang dimiliki dan diaplikasikan dalam kehidupan kerja sebelumnya bisa menjadi ukuran pada pekerjaan yang baru. Tidak adanya tantangan dalam kehidupan kerja yang dimiliki oleh seseorang mampu berakibat pada hilangnya semangat kerja bahkan bisa memunculkan keinginan untuk keluar dari pekerjaan tersebut.

Perubahan yang terjadi dalam konteks restrukturisasi organisasi menimbulkan berbagai macam dampak bagi para karyawan, baik secara fisik (misalnya; perpindahan kantor, perubahan SAjabatan, dan perubahan pekerjaan) maupun secara psikis (yaitu; was-was, khawatir, stress). Respon atau dampak yang muncul bagi karyawan memang beragam, hal ini desebabkan berbagai macam faktor yang mempengaruhinya, apakah kesiapan kerjanya, atau ketidak mampuan menghadapi perubahan dalam organisasi.

Terjadinya perubahan dalam organisasi mampu menyebabkan stres pada karyawan, hal ini terjadi karena perubahan dalam organisasi biasanya diikuti oleh perubahan pola kerja serta hubungan didalam pekerjaan, timbulnya ketidak pastian dalam organisasi inilah sebenarnya yang membawa dampak stres dan tekanan bagi karyawan, apalagi ketika proses perubahan dilihat sebagai sesuatu yang tidak menguntungkan bagi karyawan (Daft, 2004; Smitter., Houston., \& McIntire, 1996).

Karyawan yang mampu memiliki karakter "pembelajar" akan lebih mampu bertahan dalam proses perubahan organisasi, hal ini dimungkinkan karena karyawan yang memiliki kemampuan belajar yang terus menerus akan mampu dengan cepat menyesuaikan dengan karakter dan situasi yang muncul dalam proses perubahan organisasi (Smither, Houston, McIntire, 1996; Cumings \& Worley 2005). Berkenaan dengan hal tersebut, gambaran yang dijelaskan oleh Krietner \& Kinicki (2003), bahwa emosi negatif yang muncul dalam diri seseorang dipicu oleh keputusasaan dan kegagalan dalam mencapai tujuan, sedangkan emosi positif muncul dalam situasi 
pencapaian tujuan. Emosi yang mengarah kepada hal yang negatif dalam proses perubahan organisasi yang dipaparkan oleh responden lebih disebabkan oleh adanya ketidak pastian dalam proses perubahan organisasi.

Proses belajar yang terus menerus yang dimiliki karyawan dianggap mampu membantu proses penyesuaian diri karyawan dalm perubahan oganisasi, akan tetapi hal yang penting dilakukan untuk mencapai kemampuan belajar dalam proses perubahan adalah penemuan diri (self-discovery), penemuan diri ini berbentuk kesadaran akan diri yang muncul dalam proses perubahan organisasi dalam hal melihat diri dan potensi diri dalam bertahan dan berkembang dalam proses yang sedang berlangsung (Himam, 2002).

Penggunaan karyawan yang terlebih dahulu berada dalam posisi yang ditempati karyawan sebagai pembimbing dalam memasuki pekerjaan baru, dapat menjadi salah satu strategi penyesuaian kerja, begitupun dengan bersosialisasi dalam posisi yang baru mampu mendukung kemampuan untuk bertahan dan mengembangkan diri dalam proses perubahan organisasi, hal ini senada yang diungkapkan Himam (2002) dalam penelitiannya yaitu tentang strategi mengembangkan relasi (collegiality) dalam proses perubahan organisasi. Mengembangkan relasi dalam situasi perubahan organisasi akan dapat membantu karyawan untuk bertahan dalam situasi perubahan. Rekan sejawat dalam organisasi akan dapat memberi dukungan dalam menjalani proses penyesuaian diri dalam situasi yang terus berubah.

Karyawan dituntut untuk melakukan proses adaptasi yang baik dalam mengahadapi resturkturisasi orgnanisasi yang terus berlangsung, adaptasi karyawan tersebut bisa saja dicapai dengan baik ketika karyawan memiliki karakter "fleksibel". Fleksibilitas yang dimiliki karyawan yang dijelaskan oleh Spencer \& Spencer (1993), adalah kemampuan untuk menyesuaikan dengan berbagai situasi, individu atau kelompok, hal ini juga berkaitan dengan kemampuan untuk memahami dan mengapresiasi suatu perspektif yang berbeda, kemampuan inilah yang mampu membawa individu untuk mengadaptasi sebuah perubahan dan membantu individu untuk menerima peberubahan dalam organisasi dan pekerjaannya.

Munculnya karakter "sempalan" dalam proses perubahan organisasi disebabkan oleh perasaan keterlibatan yang tidak maksimal dan adanya potensi yang dirasakan karyawan yang tidak tersalurkan pada kondisi pekerjaan yang baru. Mishra dan Spreitzer (1998) "Sempalan" mampu memunculkan kritik yang destruktif yang sifatnya menyerang bagi organisasi bahkan kritik yang dimunculkan bisa berbentuk ktidak patuhan dan pembangkangan terhadap aturan organisasi.

Pemunculan diri yang sebenarnya (true self) dalam proses restrukturisasi organisasi mendorong karyawan untuk berperilaku yang sewajarnya, berbeda halnya ketika karyawan memunculkan diri yang berbeda dari yang sebenarnya, atau menggunakan "taktik menyembunyikan diri" yang dijelaskan lebih jauh oleh Himam (2002), misalnya; para karyawan tiba-tiba rajin dikarenakan terjadi proses penilaian, atau malah karyawan jadi malas-malasan dikarenakan merasa "takut" dinilai "purapura" rajin agar terhindar dari PHK yang sedang berlangsung. Konsep pemunculan diri yang berbeda ini yang disebutkan oleh Jung dalam Hall \& Lindzey (1993) sebagai bentuk "persona" atau topeng yang dipakai oleh seseorang atau sang pribadi untuk merespon tuntutan yang yang muncul pada lingkungan sosial. Pengurangan karyawan dalam organisasi dan proses penyeleksian ulang karyawan yang berlangsung dalam restrukturisasi organisasi membawa dampak pada sebagian karyawan "berpura-pura" rajin agar mendapatkan penilaian yang positif dari pihak manajemen organisasi. 
Pemunculan diri dalam konteks yang berbeda dengan yang sebenarnya akan berpengaruh pada proses pengembangan diri dalam organisasi (self enhancement), jadi kekacauan identitas diri (self identity) bisa saja muncul disebabkan oleh adanya keberpura-puraan dalam menghadapi realitas yang ada. Kegagalan mengidentifikasi diri pada karakteristik atau kelompok yang muncul dalam organisasi juga akan mampu membawa dampak manifestasi pikiran atau pada perilaku karyawan (Maiping, 1996).

Berdasarkan pemaparan diatas dapat disimpulkan bahwa perubahan organisasi, khususnya restrukturisasi organisasi selalu membawa dampak pada diri individu terutama dampak psikologis. Restrukturisasi yang dilakukan dalam perusahaan juga dapat memunculkan berbagai macam karakteristik lingkungan yang baru dalam organisasi baik relasi kerja maupun tugas dan tanggung jawab dari karyawan. Menyikapi secara positif dan optimis dapat mampu membantu karyawan untuk bertahan dan mengembangkan diri dalam kondisi organisasi yang tidak dapat diprediksi.

\section{Simpulan}

Perubahan organisasi yang berbentuk restrukturisasi adalah bentuk perubahan yang sifatnya innovatife change atau perubahan yang memunculkan biaya dan ketidak pastian, apalagi perubahan ini sifatnya radikal sehingga menimbulkan implikasi langsung yang besar pada semua lapisan karyawan. Tuntutan yang muncul dari perubahan organisasi maupun dari diri karyawan sendiri menimbulkan implikasi pada proses identifikasi diri yang mengarah pada pembentukan identitas karyawan dalam organisasi. Arah pembentukan identitas pada diri karyawan pun akan berbeda, hal ini tergantung pada tuntutan kerja, lingkungan kerja maupun tuntutan keluarga, bahkan pembentukan identitas diri (self identity) ini tidak terlepas dari peran diri dalam mengadaptasi proses perubahan yang terus berlangsung dalam organisasi. Saran bagi peneliti selanjutnya untuk mengmbangkan penelitian yang memiliki durasi yang lebih panjang atau bahkan pendekatan longitudinal agar dapat melihat dengan jelas arah perkembangan identitas organsiasi pasca perubahan organsiasi.

\section{Daftar Pustaka}

Chen, S., Chen, Y. K., \& Shaw, L. (2004). Self-verification motives at collective level of self-definition. Journal of Personality and Social Psychology, 86, 77-94.

Cummings, T.G. \& Worley, C.G. (2005). Organizational development $\left(8^{\text {th }}\right.$ ed.). SouthWestern Edition: Thompson.

Daft, R. L. (2004). Organization Theory and Design (8th ed.). South-Western:

Publishers.

Fuller, J. B., Marler L., Hester, K., Frey, L \& Relyea, C. (2006). Construed External Image and Organizational Identification: A test of Moderating Influence of Need for Self-Esteem. Journal of Social Psychology, 146, 701-706.

Himam, F. (2002) Inventing The Future: A Meta-etnographic Analysisi Towards Understanding The Process of Individual and Organizational Adaptive 
Strategies to Change, Unpublish Doctoral Dissertation, University of NebraskaLincoln, Nebraska, USA.

Himam, F. (2005). Absorbing the Wave of Change: A Grounded Case Study in Explaining Change Behavior in Organization. Jurnal Psikologi. 32, 1. 13 - 23.

Kreitner, R \& Kinicki, A. (2003). Organizational Behavior. New York: McGrow-Hill Companies. Inc.

Luthans, F. (2002). The need for meaning of Positive Organizational Behaviour. Journal of Organizational Behaviour, 23, 695-706.

Maiping C. (1996). Identity in Asian Literature. Padstow, Cornwall, Curzon Press.

Mason R. (2004). Organizational Change Models. Futurics, 28, 59-82.

Mishra, A. K. \& Spreitzer, G. M. (1998). Explaining How Survivors Respond to Downsizing: The Role of Trust, Empowerment, Justice, and Work Redesign. Academy of Management Review, 23 (3), 567-589.

Moustakas, C. (1994). Phenomenological Research Methods. California: SAGE Publications, Inc., Thousand Oaks.

Smither,R.D., Houston, J.M, McIntire, S.A. (1996). Organization Development: Strategies for changing environments. New York: Harper Collins College Publishers.

Spencer, L. M., \& Spencer, S. M. (1993). Competence at Work; Models for Superior Performance. New York: John Wiley \& Sons, Inc.

Wood, W., Pool, G. J., Leck, K., \& Daniel, P. (1996). Self-definition, Defensive Processing, and Influence: The Normative Impact of Majority and Minority Groups. Journal of Personality and Social Psychology, 71, 1181-1193. 